\title{
6 \\ The Dollar Exchange Rate and International Monetary Cooperation
}

\author{
Ronald I. McKinnon
}

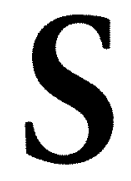

ince the early 1970 s, floating exchange rates have been associated with international cycles of inflation and deflation with the United States as the epicenter. Random and essentially arbitrary exchange fluctuations have continually misaligned national price levels-culminating in extreme dollar overvaluation throughout most of the 1980s. In order to seal off domestic markets from these precipitate changes in foreign competitive pressure, a worldwide upsurge in protectionism has occurred-particularly in the United States.

But the international business cycle can be tamed with a better alignment of exchange rates if the principal industrial countries agree to coordinate their monetary policies. A set of rules is suggested for having the United States, Germany (representing the European bloc), and Japan symmetrically adjust their internal money growth rates so as to keep their exchange rates within officially announced target zones. The common price level would be stabilized through smoother growth in their joint money supply.

Only for the United States need such an agreement require a major change in the way in which monetary policy is currently conducted. By taking this more "open-economy" approach, however, the U.S. Federal Reserve System can do a better job of stabilizing the U.S. economy and the purchasing power of the dollar.

\section{Dollar Overvaluation from 1981 to Mid-1985}

Nobody can deny the great protectionist pressure that developed in the United States in the early 1980s. Nor is there doubt that from 1981 through

Additional empirical and theoretical support for the proposals advanced in this chapter can be found in the author's recent book, An International Standard for Monetary Stabilization, published by the Institute for International Economics (Washington, D.C.) and the MIT Press (Cambridge, Mass.), 1984. I would like to thank Kenichi Ohno for his great help in preparing this chapter. 
mid-1985, the extraordinary appreciation of the dollar against European currencies - and to a lesser extent against the Japanese yen - was the major force behind the protectionist momentum. From the overvalued dollar, the United States developed symptoms of a dual economy: buoyant output in the nontradable sectors such as services of all kinds and military procurement, with depression in agriculture, mining, and most of civilian manufacturing open to foreign competition.

However increased protectionism would have been no solution at all. Reneging on the long-standing U.S. commitment to maintain free international trade would invite foreign retaliation, while undermining the economic basis for the postwar prosperity of the industrial world. In addition, restricting imports entering the United States - while international financial pressure in favor of the dollar remained unchanged-would reduce U.S. demand for foreign currency and drive the dollar up further. U.S. exporters would then be doubly hurt through the higher dollar on the one hand and because of higher dollar prices of importable inputs on the other.

But to thwart protectionism, the continual tendency toward financial imbalance between the United States and the industrial countries of Western Europe and Japan must be righted. The large U.S. fiscal deficit is commonly (and correctly) blamed for much of the trade deficit-but it cannot explain why the dollar exchange rate got so far out of line. I hypothesize that monetary coordination among the United States, the European bloc, and Japan is the only practical way of first correcting dollar overvaluation (or undervaluation) and the preserving longer-run price and exchange rate stability.

\section{The Fiscal Conundrum}

However, the most common explanation of why the dollar became overvalued points to fiscal policy rather than misplaced monetary policy.

Huge budget deficits, which the Federal Reserve refused to monetize, increased interest rates on dollar assets in real terms - after future U.S. price inflation is discounted. As capital was attracted from abroad in the early 1980s, the dollar was bid up in the foreign exchanges and overshot its longrun equilibrium until expected dollar depreciation offset the relatively high yields on U.S. government bonds and corporate securities. In the meantime, the unduly appreciated dollar depressed U.S. exports and stimulated imports.

This conventional argument sees a monotonic chain of causation: from budget deficits to interest rates to the dollar exchange rate to the trade deficit. It originated in 1981, when U.S. interest rates rose sharply - in response to the projected Reagan budget deficits and monetary tightness by the Federal Reserve-and the dollar also rose strongly in the foreign exchanges. The implication is that the U.S. fiscal deficit must be largely eliminated before the dollar's overvaluation can be overcome. 
The alternative view, to be developed here, suggests that monetary policy may be assigned to stabilize the exchange rate in the face of substantial shifts in fiscal policy. Trade deficits would still develop to match budget deficits even if the nominal exchange rate did not jump and overshoot. One must distinguish the investment-savings imbalance (which determines the trade deficit) from whatever the exchange rate regime happens to be.

For example, suppose the United States had been on a fixed nominal exchange rate when the large budgetary deficits began to develop. Then a deficit in U.S. trade, of the same order of magnitude currently observable, would still have evolved-perhaps it would have evolved even earlier. The U.S. business downturn of 1982 would have been less severe if the Federal Reserve System had been obligated to have less tight money in order to prevent the dollar from appreciating so precipitately. With better maintained domestic income, U.S. imports would have been higher in the 1982-83 period.

The fundamental point is that, when capital is internationally mobile, nations will readily develop deficits or surpluses in the current account of the balance of payments under fixed exchange rates - as, say, under the late nineteenth century gold standard. At the present time, for example, the U.S. trade deficit will remain very large as long as the government fiscal deficit continues to force expenditures above income by creating a deficiency in saving throughout the U.S. economy. A better aligned (lower-valued) dollar would, however, ameliorate the depression in U.S. tradable goods industries even if it would not do much to correct the trade deficit per se.

That there is no necessary relationship between fiscal deficits and movements in nominal exchange rates can be seen from another angle. After all, few would claim that the large dollar depreciations of the 1970 s were caused by U.S. budgetary surpluses. Indeed, the United States ran fiscal deficitsalbeit much smaller ones - in those years. The large fiscal deficits in France after Mitterrand came into power in 1981 seemed to weaken the franc rather than strengthen it.

Furthermore, no monotonic or otherwise stable relationships seem to exist between nominal interest rates and a currency's strength in the foreign exchanges. Indeed much of the extraordinary rise in the dollar exchange rate from mid-1984 to the first quarter of 1985 was associated with falling U.S. interest rates. Specifically, from August 1984 to February 1985, U.S. interest rates fell 2 to 3 percentage points relative to those in Germany while the dollar was rising from 2.88 to 3.25 marks.

Although interest rates remain important, expectations of future political safety, price inflation, and other sources of future exchange rate movements often dominate the portfolio preferences of international investors. The gnomes of Zurich, Luxembourg, and Singapore continually look for the safest haven (currency) in which to place their internationally liquid assets.

Suppose the U.S. government moved seriously toward cutting expendi- 
tures. U.S. interest rates would fall immediately in anticipation of lower future fiscal deficits, and this effect by itself would tend to depress the dollar in the foreign exchanges. Against this, people might expect that the resulting reduction in the projected national debt would lessen the chances of price inflation in the distant future. Similarly, other taxes on the holders of dollar assets become less likely. The United States could then seem like an even safer haven for international capital.

Because of these opposing considerations, even resolute action by the U.S. government to eliminate its unsustainable fiscal deficit need not bring the dollar down in the foreign exchange markets-although it probably would. (The one dramatic exception is a general withholding tax on interest and dividend income, including that from all those U.S. securities owned by foreigners. That certainly would bring the dollar down.) At best, fiscal policy is a blunt instrument, subject to long delays and uncertainties, for influencing the exchange rate.

\section{Enter Monetary Policy}

In contrast, monetary policy is immediately flexible and can be made to influence the exchange rate unambiguously. From the nineteenth century gold standard to the fixed exchange rates of the 1950s and 1960s under the old Bretton Woods agreement, examples abound of countries successfully subordinating their monetary policies to maintaining a fixed exchange rate with some other stable money. Central banks can react quickly to international shifts in the demand for the money they issue.

In the asymmetrical Bretton Woods system, countries other than the United States were directly responsible for maintaining their exchange rates within 1 percent of either side of their formal dollar parities. For example, from 1950 to 1970, the Bank of Japan kept the yen within three-quarters of 1 percent of 360 yen to the dollar by raising yen interest rates and contracting them when international payments were in deficit, and expanding the yen money supply when the Japanese currency tended to appreciate. Japanese monetary policy, based on this fixed exchange rate rule, led to stable yen prices for the broad range of internationally traded goods and contributed to Japan's extraordinary postwar recovery.

Similarly, in these same two prosperous decades, European governments generally subordinated their monetary policies to preserve stable exchange rates for long periods - with small, infrequent adjustments in their dollar parities. Only Britain continually resisted the necessary internationalization of its domestic monetary policy with consequent balance of payments deficits and numerous sterling crises throughout the 1950s and 1960s. And Britain had the least succesful domestic growth and foreign trade performances of any Western European economy. 


\section{he Flaw in Bretton Woods}

ut the Bretton Woods system had an inherent weakness. The monetary pol:y of the center country, the United States, was insufficiently guided by any xchange rate or other international obligation of its own. Even the U.S. smmitment to a weak form of gold convertibility, which was itself inadeuate, had eroded by the late 1960 s.

Consequently, in 1970-73, the international system of fixed exchange ates broke down when the United States increased U.S. money growth espite the fact that the dollar was under obvious downward pressure in the reign exchanges, as shown in table 6-1. In 1971, President Nixon mistkenly forced the other governments to let the dollar be devalued rather than ontract the U.S. money supply. Private investors took this as a signal to :duce their holding of dollar assets in favor of foreign currencies, forcing irther depreciations of the dollar in 1972-73, as shown in figure 6-1.

The resulting great inflation in the dollar prices of goods and services in re 1970s (see table 6-2) was aggravated by another unwarranted depreciaon of the dollar in 1977-79. Foreign governments became loathe to bend reir monetary policies to reestablish fixed dollar parities with what they then iw to be a chronically depreciating international currency.

Responding firmly, albeit belatedly, to domestic price inflation, the U.S. ederal Reserve System tightened up its monetary control procedures in Ictober 1979. But international confidence in the dollar was not restored un1 the election of a more conservative president in late 1980. The remarkable ift in portfolio preferences back into dollar assets, and the great dollar ppreciation of 1981-82, surprised everyone. In response to this clear signal om the foreign exchanges that U.S. monetary policy was now too tight, the ed did not loosen up soon enough. The result was the sharp deflation and epression of 1982 .

That changes in the dollar exchange rate are an excellent leading indicair of inflation or deflation to come within the U.S. economy is clearly shown I figure 6-2. Although spread out for more than two years, the lagged npact of a change in the exchange rate on the U.S. Wholesale Price Index XPI) seems to peak after five quarters. Thus figure 6-2 plots current ranges in the WPI against changes in the dollar exchange rate five quarters arlier. Since floating exchange rates began in the early 1970 s, the negative srrelation is easily visible and quite remarkable: -0.528 with the nsmoothed quarterly data and -0.817 when smoothed with a five-quarter oving average.

Tradable goods are heavily represented in the WPI and that index is natrally more sensitive to exchange rate changes. But even the U.S. GNP eflator, with its large component of nontradable services, is sensitive with schange rate effects peaking after eight quarters (McKinnon, 1985). Thus ue can see that having the Fed key on the dollar exchange rate is quite constent with its most basic objective: to stabilize the domestic U.S. price level. 


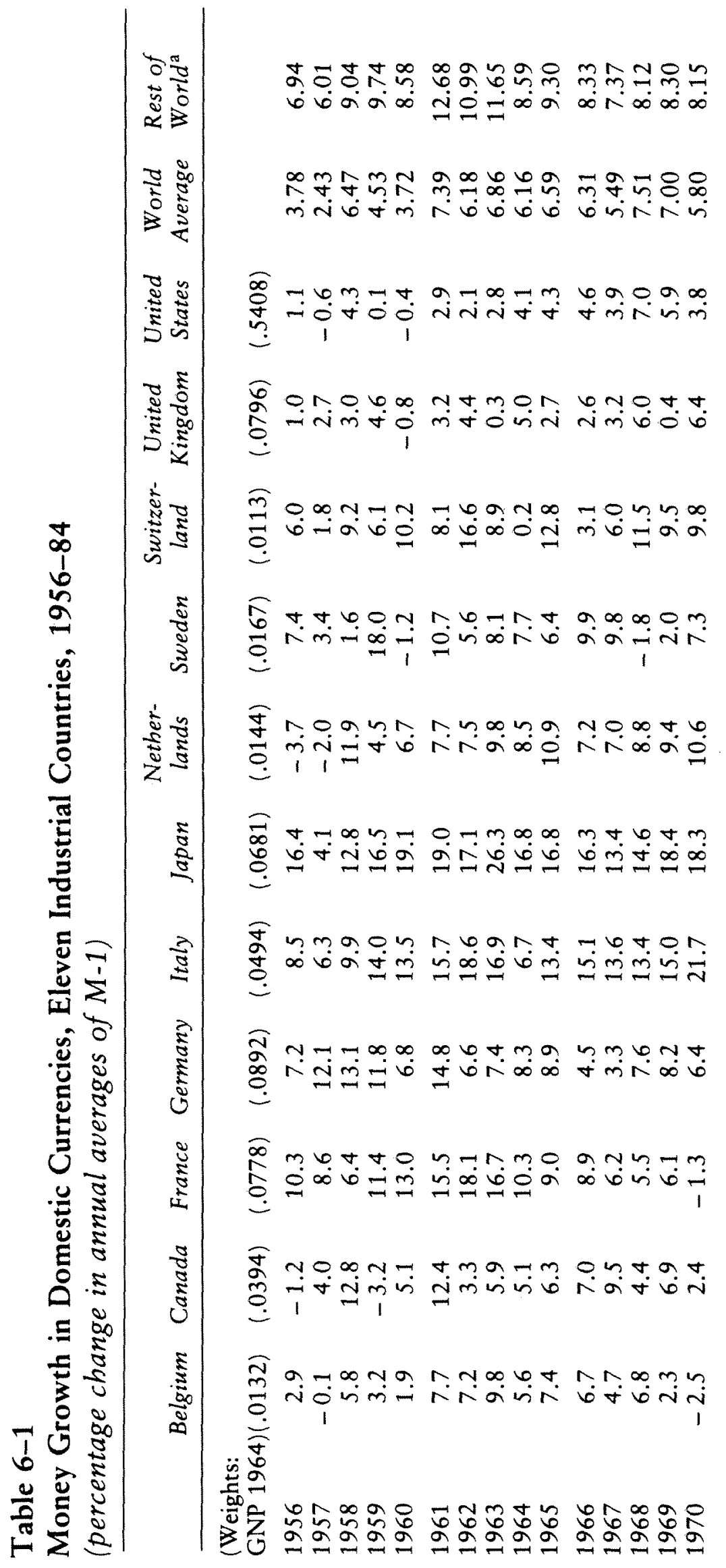


The Dollar Exchange Rate • 217

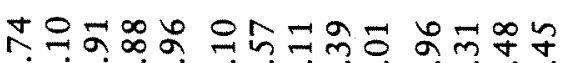
ம்

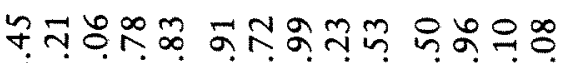

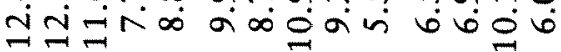

อ भु

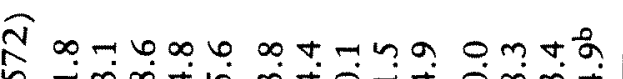
合 क n+ontmnNo+a-lon б б̆ 旁

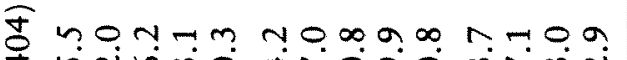

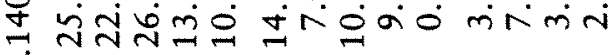

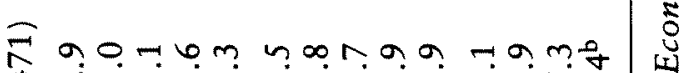

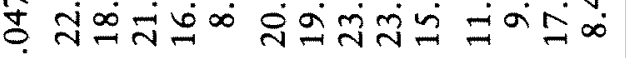
疍 万ิ noglog onn no man

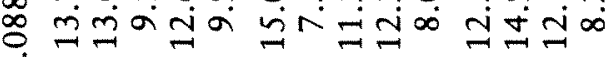
西

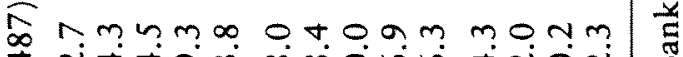

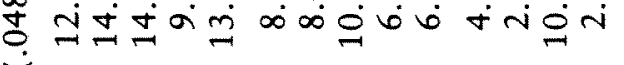

กิ momot bonmn b.tom

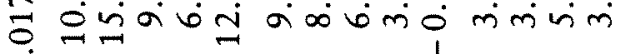
苍余 $\stackrel{\Xi}{\circ}$ 


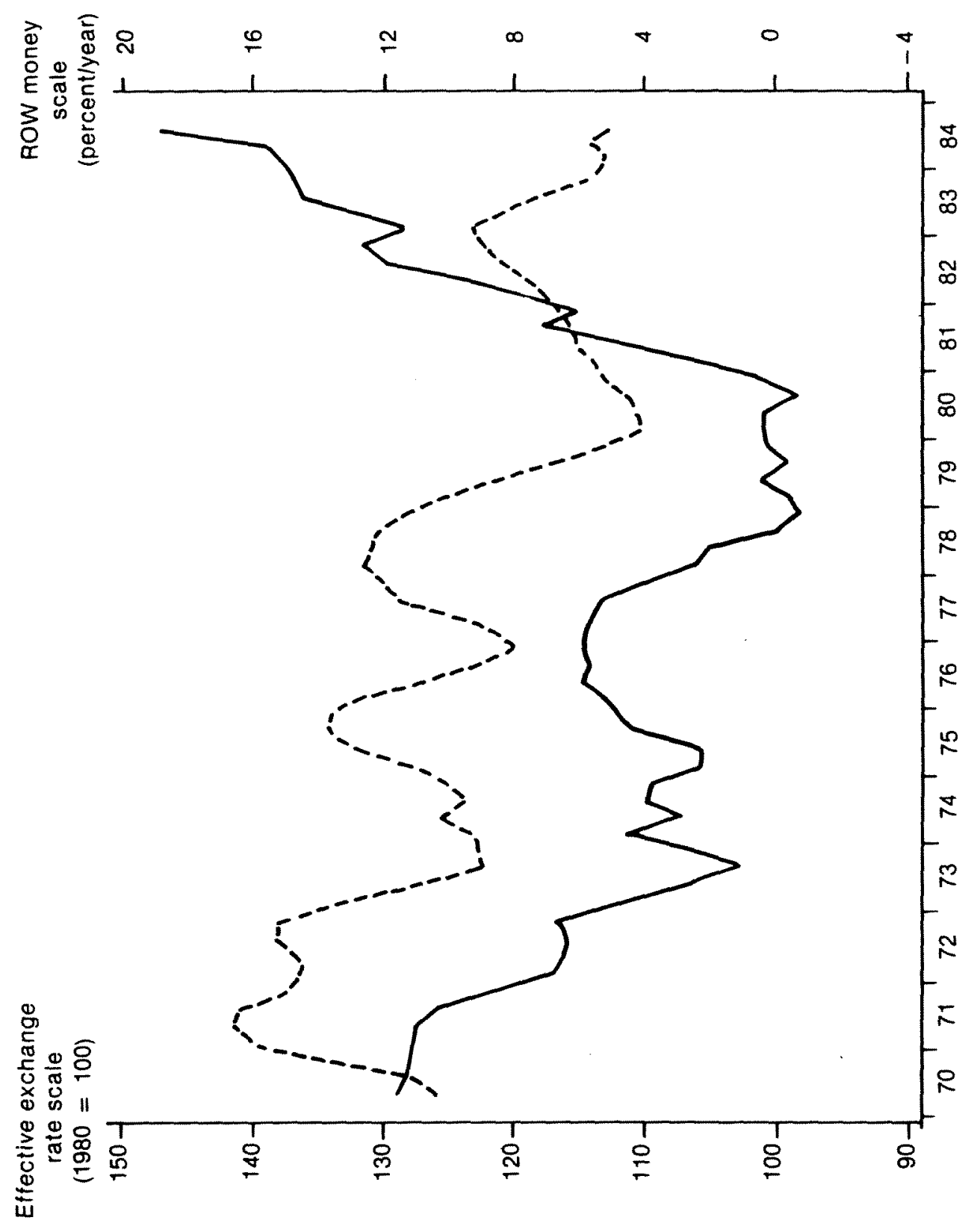


Although threatening to undermine the U.S. free trade ethic, the overvaluation of the dollar in the early 1980s had one significant advantage. The international concern over chronic U.S. inflation is now largely dissipated. Indeed, Japan has deflation while Germany and the United States have similarly low rates of price inflation, as shown in table 6-2. Thus 1985 is a good time to negotiate a new agreement for stabilizing exchange rates-at a much lower foreign exchange value for the dollar-while keeping international price inflation close to zero (see addendum).

For any new exchange rate agreement to be successful, however, the flaw in the old one must be corrected. In cooperation with other central banks, the U.S. Federal Reserve System must give exchange rate stability more weight in the future conduct of U.S. monetary policy. Speculative pressure is now too great for Japan or European countries to stabilize dollar exchange rates on their own; many have tried (and failed) to do so in recent years - particularly in the turbulent months of late 1984 and early 1985 .

\section{A New Monetary Order for the 1980s}

Assume now that in making U.S. monetary policy, the Federal Reserve System abandons its traditional insular approach, which virtually ignores the foreign exchanges. By some miracle, suppose that the Bank of Japan, the Bundesbank (representing the European bloc), and the Fed all agree to coordinate their monetary policies to achieve exchange stability.

How could such a system be efficiently managed to nudge the dollar down in the foreign exchanges without significant inflationary consequences? Once this transition is completed, how can fixed exchange rates and stable prices be maintained?

Announcement effects are as important as the fact of monetary cooperation itself. To harness the market's expectations in favor of the new exchange rate regime, the three central banks must spell out what they intend to do in a consistent fashion. Only then will the required adjustments in national monetary policies turn out to be minimal.

So what should the triumvirate announce? The new monetary order would have four essential elements:

1. Explicit target zones for the yen-dollar and mark-dollar exchange rates;

2. A commitment to adjust domestic monetary policies symmetrically among the three countries to achieve these targets;

3. Rules for restrained, but decisive, direct interventions to correct "disorderly conditions" in the foreign exchanges; 


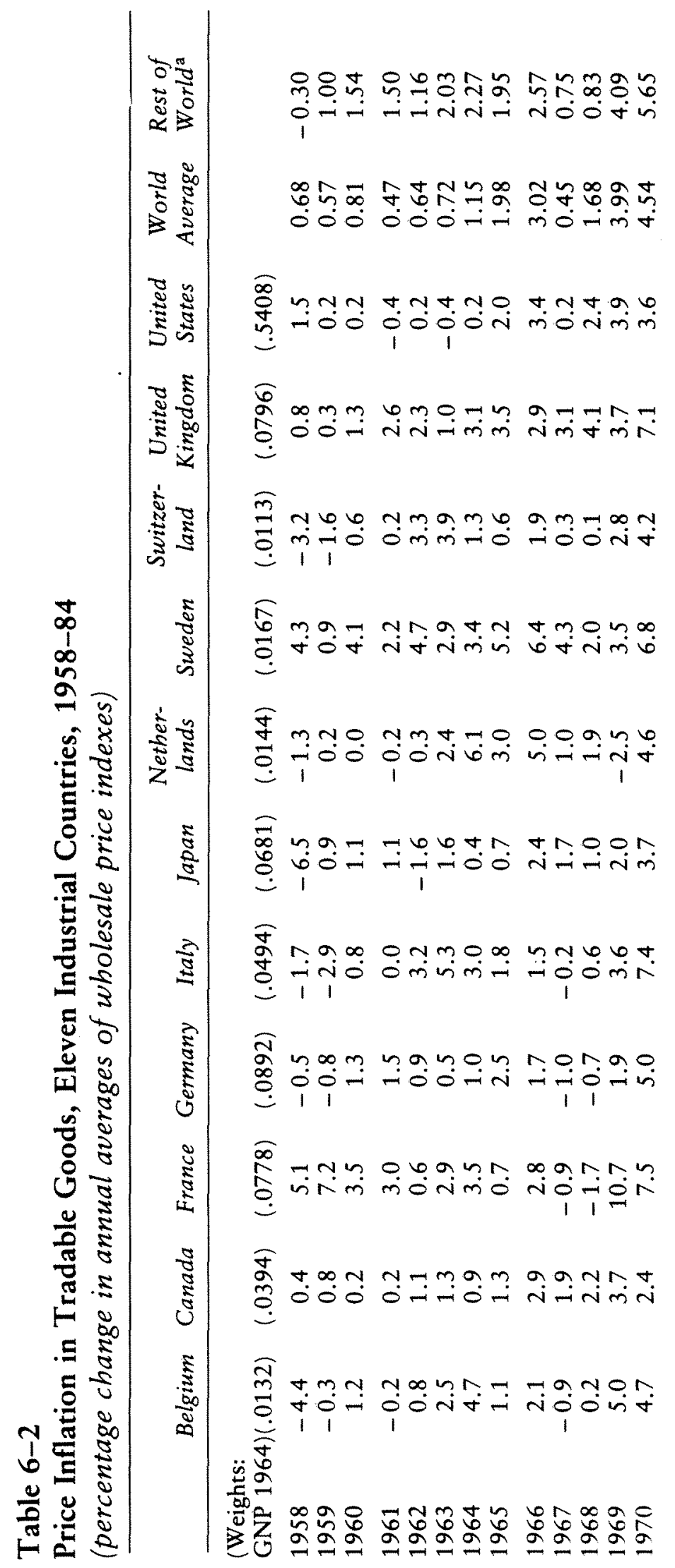




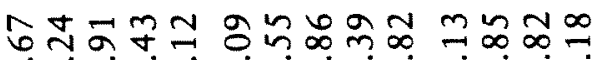

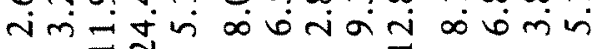

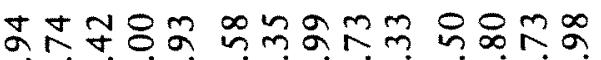
तm

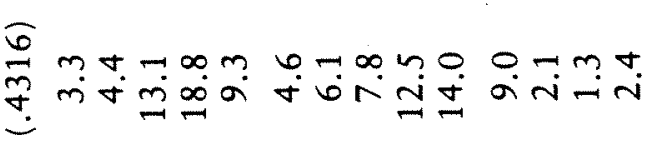
公

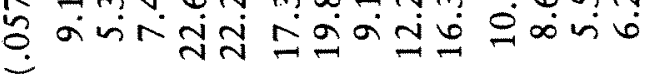
立

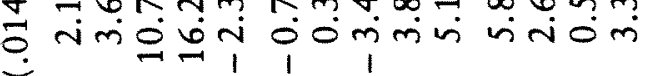
命 ปิ ปั

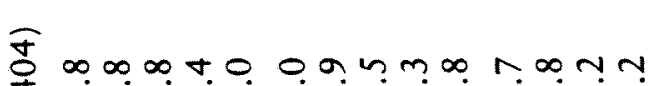

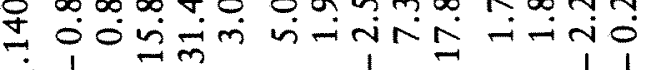

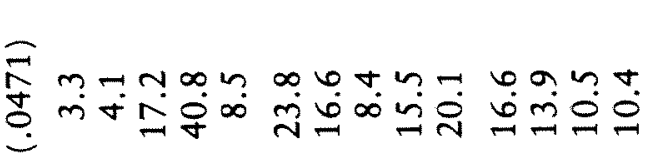
สิmnbugrnyonn roma

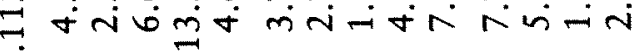

$\widehat{\Omega}-M n-n+0 m m \infty 0$ -

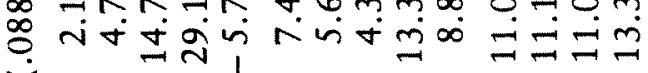
茂 A nothn-tammonhut

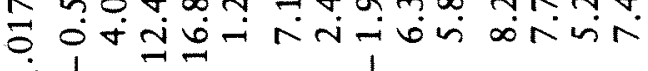

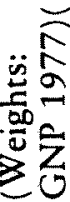

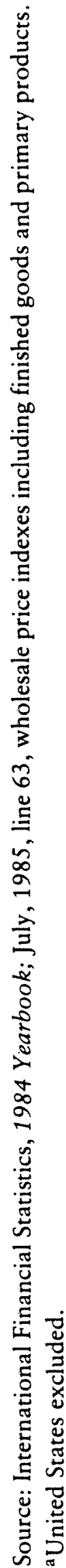




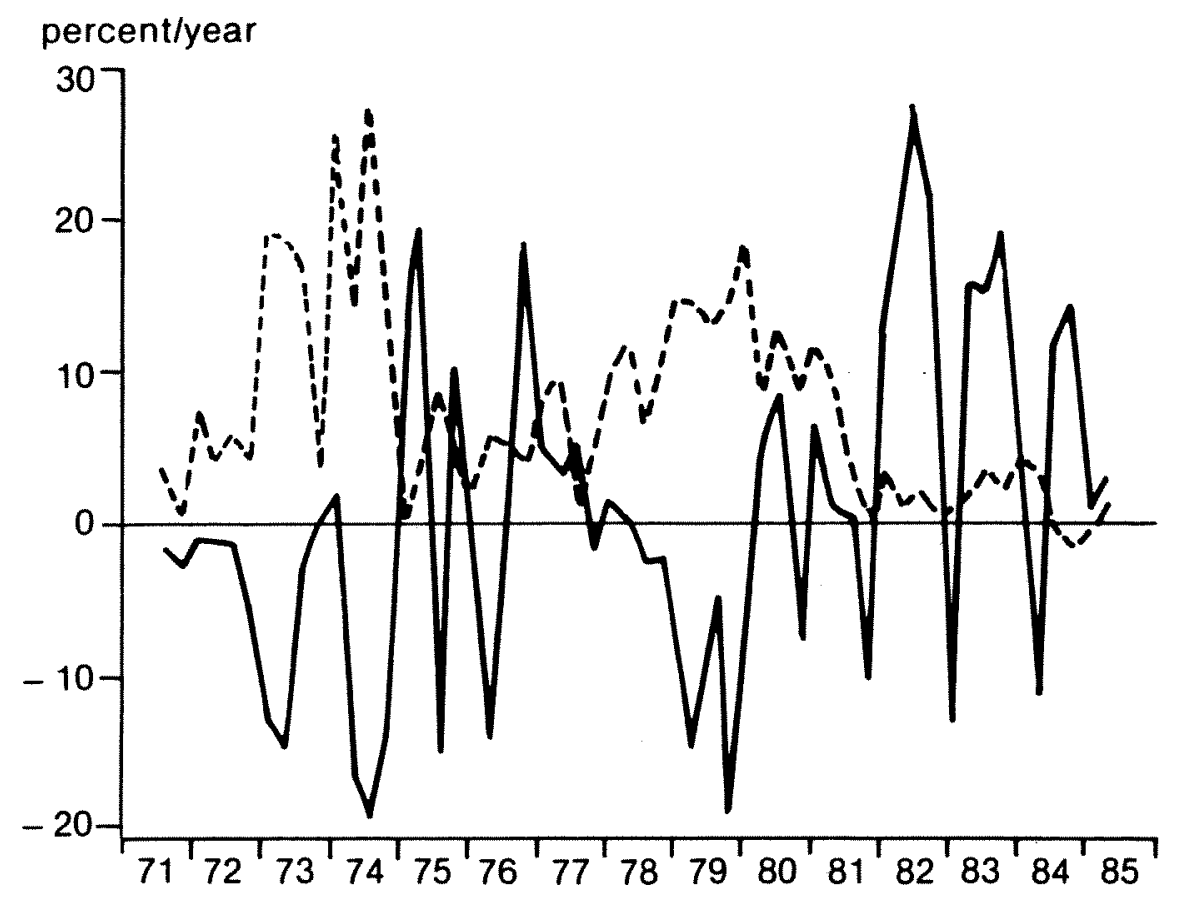

Correlation

Effective exchange rate (rate of change, lagged 5 quarters)

- WPI inflation

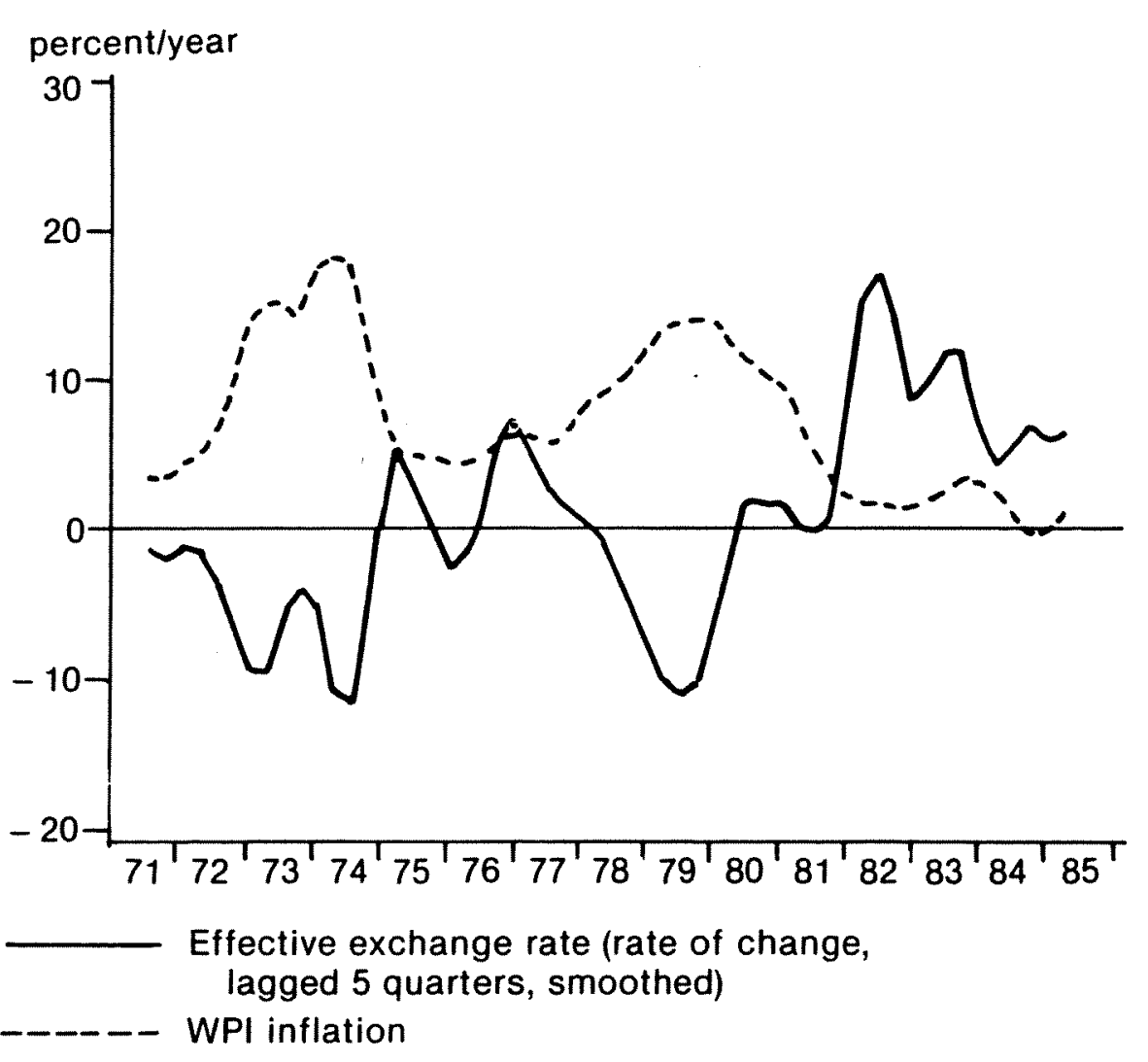

Figure 6-2. U.S. Effective Exchange Rate and the Wholesale Price Index, 1971-85 
4. Joint management of aggregate money growth within the triumvirate in order to stabilize their common price level in the longer run.

I will now discuss each in turn.

\section{Target Zones for Exchange Rates}

Exchange rate targets would be designed and announced to achieve a rough purchasing power parity among the three countries, taking their current stable price levels as benchmarks. Illustrative calculations suggest that about 2.2 marks and 210 yen to the dollar - far under today's market quotations approximate what the triumvirate should strive for.

(Warning: Economists have to understand that these exchange rate targets are designed to align national price levels, not to correct bilateral or multilateral trade deficits or surpluses. Even if the dollar were nudged down so that the U.S. price level became better aligned with those of Germany and Japan, the large U.S. fiscal deficit would still stimulate excessive consumption and leave a large U.S. trade deficit, albeit one that was somewhat smaller.)

Because of the current substantial difference in interest rates between the United States and the other two countries, a broad 10-percent band should be established around these two central rates. To illustrate, the dollar could be targeted to stay within a range of 2.10 and 2.30 marks, and within 200 to 220 yen.

In view of the present extreme misalignment of the dollar, these target zones are necessarily "soft" (Williamson, 1983). That is, the participating central banks are not committed to achieving them immediately. In particular, any massive official intervention in the foreign exchanges to push rates in the desired direction would be ruled out.

Nevertheless, the targets are real enough. The gnomes would clearly understand the direction in which the central banks were pushing. In view of the misinformation and confusion that now prevails in the exchange markets, a clear official declaration of exchange rate goals would allow private expectations to coalesce in support-provided that the accompanying program of monetary adjustment were credible.

\section{Mutual Monetary Adjustment}

Among the three countries, monetary adjustments would take place symmetrically for as long as the relevant exchange rate was outside its target zonewhether that be weeks, months, or years. When the dollar exchange rate was above its target zone(s), the Fed would expand the money supply and reduce interest rates while the Bundesbank and Bank of Japan contracted symmetric- 
ally (and act conversely if the dollar were ever to fall below its target range) In this way, the total "world" money supply would remain roughly constant but relative amounts of constituent currencies would fluctuate to meet the demand for them.

For example, suppose that the current mark-dollar exchange rate wert 2.80 , that the Fed's normal long-term annual growth rate for $M-1$ wers between 4 and 6 percent, and that the Bundesbank's normal growth in what it calls "central bank" money were also between 4 and 6 percent. Then the Fed would be publicly committed to increasing its money growth above $\epsilon$ percent (possibly reducing interest rates), while the Bundesbank would keef its money growth below 4 percent (possibly raising interest rates), until the mark-dollar rate fell below 2.3 marks and into its target zone.

To be successful in changing traders' expectations to push the markdollar exchange rate in the desired direction, this commitment to mutual monetary adjustment must be unambiguous. To avoid adverse expectations. other potentially conflicting rules need to be jettisoned.

For example, the surprisingly sharp rise of the dollar within two weeks in February 1985 from 3.2 to about 3.47 marks (DM) was due at least in part to an apparent conflict in the U.S. Federal Reserve System's immediate monetary objectives. In November and again in December 1984, the Fed cut the discount rate and embarked on much faster money growth; it correctly noted that such expansion was warranted because (among other factors) the dollar at 3.0 DM was grossly overvalued even then. And for November, December, and January, growth in U.S. M-1 spurted to more than 11 percent measured on an annual basis.

However, in January the Fed then published - as required by the U.S. Congress-its money growth targets for all of 1985. A normal 4- to 7-percent growth range for $M-1$ during 1985 was announced. Unfortunately, this published money growth target conflicted with the higher money growth actually taking place in early 1985. In February and March, actual M-1 was far above the cone of "permissible" levels officially published.

The market came to expect that the Fed would have to contract to get M-1 back on its "normal" path. In anticipation, U.S. interest rates rose sharply in February 1985, and drove the dollar up further in the foreign exchanges. This surge into dollar assets assumed panic proportions when Fed Chairman Paul Volcker, testifying before Congress on February 20, suggested that the Fed would end the progressively easier credit policy adopted in late 1984.

Clearly the Fed should have made clear that monetary ease would continue indefinitely, and that lower long-term growth in $M-1$ would not be resumed until the dollar had fallen into its target zone. Fortunately, however, the Fed did persist with a higher rate of domestic monetary expansion about 12 percent per year through mid-1985-as if it were keying on the dol- 
lar exchange without admitting it. Finally, on July 16, 1985, in its midyear report to the U.S. Congress, the Fed officially abandoned its old 1985 target of 4- to 7-percent money and "rebased" the money supply at its new higher level. It then respecified domestic money growth to be 3 to 8 percent, from this now higher base, for the remainder of 1985 .

Even without the dollar exchange rate as an official target, this massive additional monetary expansion undoubtedly helped prevent the dollar from increasing further. By mid-August 1985, it had fallen back to 2.8 marksstill considerably overvalued, and about where it was the year before. But the effect on the exchange rate was lessened because the Fed's stated intentions were (and are) somewhat ambiguous about how far it might like to push the dollar down.

The credibility of this unusual seeming attempt by the Fed to key on the exchange rate was further undermined by the absence of any agreement on how foreign central banks would react. Those countries with weak currencies - most particularly the European bloc-should have reduced their money growth below normal when the Fed undertook its unusual expansion in late 1984. Downward pressure on the dollar would then have come from both sides.

If, instead, the German and Japanese central banks behaved perversely by expanding in tandem with the Fed in 1985, the private markets would have no assurance that the dollar would be successfully pushed down. Not knowing what the other central banks were going to do, private speculators were less likely to support the Fed's actions by anticipating dollar depreciation.

Clearly, monetary adjustments by one central bank are much more likely to succeed in influencing the exchange rate if the market knows that the other two are supporting it. Thus one can see the great value of a formal, wellpublicized international agreement on the format for monetary coordination.

\section{Official Intervention in the Foreign Exchanges}

The fact, or even the possibility, of direct official intervention in the foreign exchanges captures newspaper headlines. As the U.S. government agonizes over what to do about the exchange rate, the immediate focus is on whether or not the Federal Reserve Bank of New York - in consultation with the U.S. Treasury and the Federal Reserve System-should intervene as a buyer or seller of foreign exchange.

On March 8, 1985, the Federal Reserve Bank of New York announced that it had intervened to buy deutsche marks seven times between August and January in relatively modest amounts (for this huge market) of $\$ 100$ or $\$ 200$ million in each case. The European and Japanese central banks were known to have intervened more often and more heavily over the same period. As 
usual, the Fed refused to reveal the details of its more recent and substantially heavier interventions in February and early March 1985.

But this emphasis on direct intervention is misplaced, and so is some of the secrecy that veils the precise goals of these interventions.

With the integration of the U.S., European, and Japanese capital markets, gross stocks of private financial claims on - and liabilities to-foreigners tend to dwarf official exchange reserves. For example, by the end of 1983, private Japanese claims on foreigners were about ten times as high as official exchange reserves; and with the further Japanese financial liberalization in 1984, these gross private claims again increased. In financially open European economies such as Germany and Britain, the ratios of gross private claims on foreigners to official exchange reserves are even greater than in the Japanese case.

The upshot is that exchange reserves are too small for direct government intervention to have a significant impact on the huge internationally mobile private holdings of stocks and bonds. Indeed, ample evidence in 1984-85 suggests that official attempts to intervene in the absence of monetary coordination, and without influencing the (adverse) expectations of private traders, did wash out for all practical purposes. For stabilizing the exchange rate, official intervention will be ineffective unless it is accompanied by a supporting monetary policy. And these mutual monetary adjustments - as already described-need not require direct interventions in the foreign exchanges.

That said, there remains a limited role for direct official intervention to correct disorderly conditions in exchange markets over a short period-say, one trading day.

Having posted target zones for exchange rates (according to the hypothetical monetary agreement), the triumvirate of central banks could treat as "disorderly" any substantial exchange rate movement away from these official targets. For example, if the target is 2.1 to $2.3 \mathrm{DM}$ per dollar, and the rate suddenly moves from 2.8 to 3.0 or more, then the market is disorderly: the movement is both large and in the wrong direction.

Indeed, such a perverse movement indicates either that private traders are not properly informed of official intentions or that the official exchange rate targets lack credibility. To reaffirm the central banks' objective of guiding exchange rates into their target zones, some stabilizing intervention is warranted.

To be both limited in magnitude and decisive in result, any such intervention should be reinforced by discrete monetary adjustments beyond previous measures. This is most easily accomplished by ensuring that interventions in the foreign exchanges are symmetrically unsterilized in their impact on each country's monetary base.

For example, to prevent the dollar from increasing further, suppose the 
Bundesbank - in consultation with the Fed-purchases $\$ 200$ million worth of marks in the open foreign exchange market. They could agree that the Bundesbank would retire those marks from circulation while the Fed expanded the U.S. monetary base by $\$ 200$ million. Consequently, interest rates would likely rise in Germany and fall in the United States, thus helping to drive the dollar down.

This is powerful medicine. If the distribution of monetary base between the two countries is affected, even modest official exchange interventions have great leverage, as private traders will quickly realize.

\section{Need Dollar Depreciation Be Inflationary?}

Suppose the dollar exchange rate is pushed down into the target zones just suggested. Is it possible to avoid reigniting the kind of rapid price inflation associated with the depreciating dollar of the unhappy 1970s?

Yes, because of the inherent symmetry in the above proposal for monetary coordination. When the Fed expands, the other principal central banks contract below normal growth - and vice versa. The result is no unusual growth in the monetary base for the system as a whole, even as the dollar is pushed down to its purchasing power parity.

The great dollar depreciations of the 1970s were associated with increased monetary growth in the United States coupled with sometimes explosive monetary growth in Europe and Japan, as shown in table 6-1. The reason for this loss of monetary control abroad was foreign central banks' resisting (not very successfully) having their own currencies appreciate when international portfolio preferences had shifted sharply away from dollar assets. Through direct interventions to buy dollars and sell their own monies, or through equivalent domestic monetary expansions to reduce interest rates, they lost monetary control. ${ }^{1}$

This fundamental asymmetry in the world dollar standard, where other central banks react to the dollar exchange rate but the Fed usually does not, is seen in figure 6-3. For 1971 through 1985 , one can see the strong negative correlation between percent changes in money growth in the rest of the industrial world (ROW) and percent changes in the dollar exchange rate. With unsmoothed individual quarterly observations, the simple correlation is -0.305 as shown in the upper panel. The correlation becomes stronger at -0.620 if a five-quarter moving average is used, as shown in the lower panel of figure 6-3.

The system went askew in the 1970 s because the U.S. Federal Reserve System failed to contract when international demand unexpectedly shifted into foreign currencies at a time when the dollar was not overvalued, at least not overvalued by today's standards. Because the principal player, the Fed, 

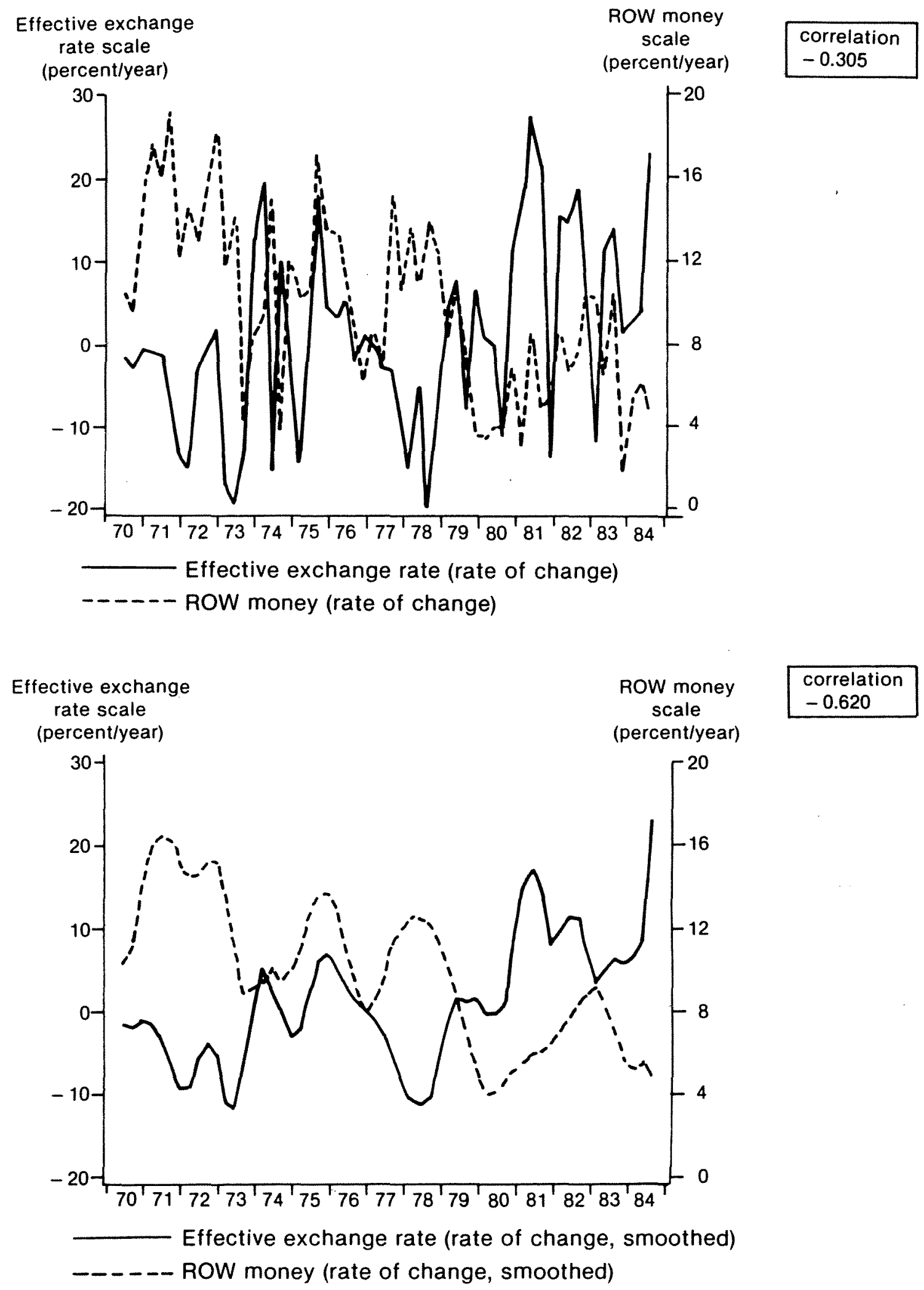

Figure 6-3. U.S. Effective Exchange Rate and Money in the Rest of the World, 1970-84 
was not playing the game correctly, the other central banks were simply overwhelmed.

Accidental or not, the great increase in "world" money growth in the 1970 s had a strong inflationary impact on the prices of internationally tradable goods, whether manufactures or primary commodities. And all the major industrial economies experienced this price inflation (see table 6-2), particularly those such as the United States whose currencies had depreciated relative to the others. Undoubtedly, these foreign monetary repercussions help explain why fluctuations in the dollar exchange rate display the strong (lagged) effects on the U.S. price level shown in figure 6-2.2

Through mid-September 1985, however, the situation was quite different. The dollar was truly overvalued by any reasonable standard. The portfolio pressure in the foreign exchanges was strongly in favor of dollar assets which increases the derived demand for U.S. base money. The situation was one of price stability-indeed, one of undue deflationary pressure in those sectors of the U.S. economy that must compete on world markets.

In these circumstances, it would be relatively safe to increase monetary expansion in the United States to drive the dollar down - and dangerous not to. But as long as the Fed remains expansionary, the other central banks must agree to maintain tight money during the transitional correction in the dollar exchange rate. Once exchange rates were aligned, the three central banks would, ideally, have also agreed to manage their joint money supply to stabilize the common price level into the indefinite future. Then private expectations would be favorable, and the unfortunate inflationary experience of the 1970 s need not be repeated.

Of course, even if the dollar depreciates under these controlled circumstances, there will be a one-time increase in the dollar prices of tradable goods, and a simultaneous decrease in their prices when measured in marks or yen. But this change in relative prices is necessary to rescue unprotected American farmers, manufacturers, and miners from heavy taxation imposed on them by the dollar's overvaluation, and to prevent an outbreak of protectionism in the United States.

After this one-and-for-all correction in the dollar exchange rate, the principal central banks would begin their regular program of ongoing coordination. Nominal exchange rates would be kept within their preassigned bands and the common international price level would be better stabilized into the indefinite future. Governments could then more realistically negotiate new rounds of the General Agreement on Tariff and Trade (GATT) to remove nontariff barriers - many of which developed in the era of floating exchange rates-and the modest remaining tariff barriers. With a sufficiently stable international price level, even the difficult job of liberalizing trade in agricultural products would be more likely to succeed. 


\section{Addendum}

After these comments were completed, on the weekend of September 21-22, 1985 , a major exchange rate agreement was announced among the finance ministers and central bank heads of the five principal industrial countries: Britain, France, Germany, Japan, and the United States. Their stated intention was to undertake strong financial measures (measures not spelled out) to drive the dollar down. The announcement's effect was quite dramatic - the dollar fell by more than 10 percent over two trading days. That a better alignment for the dollar exchange rate has now become an objective of official policy is a major step forward in the preservation of free international trade.

On the other hand, it is far from clear that the officials involved have worked out a sufficiently coordinated program of mutual and symmetrical monetary adjustment, as sketched above, to sustain a better alignment of exchange rates and preserve price stability into the future. No details of a monetary program were released at the September meeting. Rather, the emphasis seemed to be on massive official interventions in the foreign exchange markets - which, however big, will tend to wash out unless the market views such interventions as harbingers of monetary adjustment to come.

Similarly, the agreement hinted that the Europeans and Japanese would cut taxes. But, as just suggested, the exchange rate effects of such fiscal adjustments by themselves are ambiguous.

Whether a coherent program of monetary coordination successfully evolves remains to be seen. However, the signs now, in January 1986, seem more favorable than I had previously dared hope.

Throughout 1985, the three principal central banks in fact supported the intentions of U.S., Japanese, and European officials to drive the dollar down. Growth in U.S. $M-1$ was a relatively expansionary 12 percent, whereas German and Japanese $M-1$ growth was much more restrained-about 5.5 percent. Equally important, the governor of the Bank of Japan formally announced on October 24, 1985, that, in order to keep the yen down in the foreign exchange markets, Japanese money growth would be restricted for the rest of the year.

The result of these several actions was an engineered fall in the dollar from as much as 3.4 DM and 260 yen in February 1985 to about 2.45 marks and 200 yen by December. These nominal rates are now (January 1986) much closer to any reasonable estimate of purchasing power parity.

However, the exchange system is not yet secured by a well-understood international agreement on future monetary coordination. If, for example, the dollar were to begin falling sharply to much below its present rough purchasing power parity, the three central banks should be prepared to quickly reverse roles: the Federal Reserve should tighten up as the Bundesbank and 
Bank of Japan both undertook monetary ease. Then one could rest better assured that the principle of symmetrical monetary coordination had finally been accepted.

\section{Notes}

1. For a more complete description of how the international money multiplier works, see R. McKinnon (1982).

2. This chapter has not dealt with the precise definition of monetary targets for the three countries that would secure price stability in the longer run. This subject is treated in McKinnon, 1984, chap. 5. Such a monetary program would avoid sharp changes in the collective money supply while gearing its long-term growth to maintain a stable purchasing power over a common, broad basket of internationally tradable goods.

\section{References}

Frenkel, Jacob, and Michael Mussa. "The Efficiency of the Foreign Exchange Market and Measures of Turbulence." American Economic Review 70, no. 2 (May 1980).

- . "Asset Markets, Exchange Rates, and the Balance of Payments." In R. Jones and P. Kenen (eds.), Handbook of International Economics, vol. 2. Amsterdam: North-Holland, 1985.

McKinnon, Ronald I. "A New Tripartite Monetary Agreement or a Limping Dollar Standard?" Essays in International Finance no. 106. Princeton, N.J.: Princeton University, 1974.

- "Currency Substitution and Instability in the World Dollar Standard." American Economic Review 72, no. 80 (June 1982).

- An International Standard for Monetary Stabilization. Washington, D.C.: Institute for International Economics, 1984.

—. "The Dollar Exchange Rate as a Leading Indicator for American Monetary Policy." Palo Alto, Calif.: Stanford University, 1985 (unpublished).

Williamson, John. The Exchange Rate System. Washington, D.C.: Institute for International Economics, 1983. 